\title{
Acute Hepatitis-A Infection Induced Anemia in Concurrence of Glucose-6-Phosphate Dehydrogenase Deficiency and Thalassemia Trait: A Case Report
}

\author{
Glukoz-6-Fosfat Dehidrogenaz Eksikliği ve Talasemi Tașıyıcılığı Birlikteliğinde, Akut Hepatit-A \\ Enfeksiyonunun Tetiklediği Anemi: Bir Olgu Sunumu
}

\author{
Zafer Bıçakcı \\ Department of Pediatry, Unit of Pediatric Hematology, Kafkas University Faculty of Medicine. Kars, Turkey
}

\begin{abstract}
Thalassemia and glucose-6-phosphate dehydrogenase (G6PD) deficiency are genetic disorders causing hemolytic anemia. Coinheritance of thalassemia and G6PD deficiency can be present in regions where both hematological disorders have a high incidence. Infections may trigger hemolysis in both thalassemia and G6PD deficiency. My aim is to present a patient with both G6PD deficiency and thalassemia trait where I believe the hemolysis was triggered by acute hepatitis A virus (HAV) infection. Pallor, jaundice, growth-development retardation and hepatosplenomegaly were found in a three-year-old male patient. Laboratory tests revealed anemia, reticulocyte elevation (6\%), target cells in the peripheral smear, (+++) hemoglobin in the urine and no erythrocyte on urine microscopy. The patient's $\mathrm{HbA} 2, \mathrm{HbA}$ and $\mathrm{HbF} 2$ ratios were $4.20 \%, 76.10 \%$ and $19.7 \%$, respectively. The father's $\mathrm{HbA} 2$ was high (5.03\%) while the mother's HbA2 was normal (2.65\%). A heterozygous codon 15G/A mutation was found in the patient's beta-globulin gene DNA sequence analysis.

In conclusion, intravascular hemolysis and coinheritance of different disorders must be considered and peripheral smear (erythrocyte morphology) and urine microscopy should not be neglected if anemia and significant hyperbilirubinemia are present in patients with hepatitis $A$ infection.
\end{abstract}

Key words: thalassemia; glucose-6-phosphate dehydrogenase deficiency; hepatitis A; hemolytic anemia

\section{ÖZET}

Talasemi ve glukoz-6-fosfat dehidrogenaz (G6PD) eksikliği hemolitik anemiye neden olan genetik bozukluklardır. Her iki hematolojik bozukluğun yüksek sıklıkta görüldügü bölgelerde talasemi ile G6PD eksikliğinin birlikte kalıtımı bulunabilir. Bununla beraber,

Yard. Doç. Dr. Zafer Bıçakcı, Kafkas Üniversitesi Tip Fakültesi Çocuk Sağlı̆̆ı ve Hastalıklarn Anabilim Dalı Cocuk Hematolojisi Birimi, Paşaçayır, Kars, Türkiye, Tel.05325137271Email.zaferbicakcib@yahoo.com.tr

Gelis Taribi: 19.12.2014 • Kabul Tarihi: 16.02.2015 enfeksiyonların hem talasemide ve hem de G6PD eksikliğinde hemolizi tetiklediği bilinmektedir. Amacım; hemoliz tetiklemesini akut hepatit $A$ (HAV) virüsü enfeksiyonun yaptığını düșündügüm hem G6PD eksikliği ve hem de talasemi tașıyıcısı olan bir hastayı sunmaktır. Üç yașındaki erkek hastada, solukluk, sarılık, büyümegelișme geriliği ve hepatosplenomegali tespit edildi. Hastada anemi, retikülosit yüksekliği (\%6), periferik yaymada hedef hücre, idrarda hemoglobin (+++), idrar mikroskobisinde eritrosit negatifliği vardı. Hastanın $\mathrm{HbA2}, \mathrm{HbA}$ ve $\mathrm{HbF}$ oranları sırasıyla \%4,20, \%76,1 ve \%19,7'ydi. Babanın HbA2'si yüksek (\%5,03), annenin HbA2'si ise normal $(\% 2,65)$ olarak bulundu. Hastanın beta-globulin geni DNA dizi analizinde heterozigot codon 15G/A mutasyonu tespit edildi.

Sonuç olarak; hepatit A enfeksiyonu olan hastalarda anemi ve belirgin hiperbilirubinemi varsa intravasküler hemoliz düșünülmeli, hastalıkların birlikte kalıtımı ihtimaline karșı periferik yayma (eritrosit morfolojisi) ve idrar mikroskobisi ihmal edilmemelidir.

Anahtar kelimeler: talasemi; glukoz-6-fosfat dehidrogenaz eksikliği; hepatit A; hemolitik anemi

\section{Introduction}

Thalassemia and glucose-6-phosphate dehydrogenase (G6PD) deficiency are genetic disorders resulted with hemolytic anemia. Coinheritance of thalassemia and G6PD deficiency can be present in regions where both of the hematological disorders have high incidences. G6PD deficiency was reported in 37 of 410 thalassemia patients $(9.02 \%)$ in a study ${ }^{1}$.

Infections are known to trigger hemolysis in both thalassemia and G6PD deficiency. Although the association of G6PD deficiency and acute hepatitis A virus (HAV) infection was previously reported, I could not find a report of association of the three 
entities in the same patient ${ }^{2-5}$. My aim is to present a patient with G6PD deficiency and thalassemia trait where I believe the hemolysis was triggered by acute $\mathrm{HAV}$ infection.

\section{Case Presentation}

A three-year-old male patient diagnosed with acute HAV infection one month ago at another hospital was referred to our hospital for investigation of the etiology of icterus and anemia.

The child had growth-development retardation (height and weight 3 and $10 \%$ of children at his age), pallor, scleral icterus, hepatomegaly $(3 \mathrm{~cm}$ under the rib margin) and splenomegaly (4-5 $\mathrm{cm}$ under the rib margin) in the clinical examination.

Previous laboratory examination which was performed 10 days ago at another hospital revealed the results as follows: leukocyte count, $10.14 \times 10^{3} / \mu \mathrm{L}$; hemoglobin $(\mathrm{Hb}), 7.9 \mathrm{~g} / \mathrm{dL}$; hematocrit (Hct), 24.9\%; erythrocyte number, $4.06 \times 10^{3} / \mu \mathrm{L}$; mean corpuscular volume (MCV), $63.3 \mathrm{fL}$; mean corpuscular hemoglobin $(\mathrm{MCH}), 19.5 \mathrm{pg}$; mean corpuscular hemoglobin concentration (MCHC), $31.7 \mathrm{~g} / \mathrm{dl}$; platelets, $391 \times 10^{3} /$ $\mu \mathrm{L}$; aspartate aminotransferase (AST), $537 \mathrm{U} / \mathrm{L}$; alanine transaminase (ALT), $519 \mathrm{U} / \mathrm{L}$; total bilirubin (T.bil), $19 \mathrm{mg} / \mathrm{dL}$; direct bilirubin (D.bil), $13 \mathrm{mg} / \mathrm{dL}$; anti HAV IgG, $3.2 \mathrm{~s} / \mathrm{co}(0-1)$; and anti HAV IgM, $12.5 \mathrm{~s} / \mathrm{co}(0-1.2)$.

Laboratory findings of the patient at the moment of hospitalization were: Total bilirubin, $5.79 \mathrm{mg} / \mathrm{dL}$; direct bilirubin, $1.26 \mathrm{mg} / \mathrm{dL}$; lactate dehydrogenase $(\mathrm{LDH}), 395 \mathrm{U} / \mathrm{L}$; C-reactive protein (CRP), 1.85 $(0-0.5) \mathrm{mg} / \mathrm{dL}$; vitamin $\mathrm{B}_{12}, 373.9 \mathrm{pg} / \mathrm{mL}$; and folate,
$5.87 \mathrm{ng} / \mathrm{ml}$. During further examination, fragmented erythrocytes, target cells, a few normoblasts, anisocytosis, poikilocytosis and polychromasia were seen in the peripheral blood smear (Fig. 1). Hemolytic anemia was considered due to the presence of anemia, icterus and hepatosplenomegaly in addition to the peripheral blood smear findings. Also, a reticulocyte value and corrected reticulocyte percentage were $6.34 \%$ and $3 \%$, respectively. Further laboratory examination for hemolytic anemia revealed a negative direct Coombs' test, normal osmotic fragility, $0.316 \mathrm{U} / \mathrm{g}$, G6PD; 44.7 $\mathrm{mg} / \mathrm{dL}(36-195)$ of haptoglobin. There was $(+++)$ hemoglobin in the urine with no erythrocytes or cells. Hemoglobin electrophoresis results were as follows: $\mathrm{HbA}_{2}$, 4.2\% (1.5-3.7); HbA, 76.10\% (94-99); and $\mathrm{HbF}, 19.7$ (0-2). Among examined serological tests, Anti-HAV IgM was positive while brucellosis, HIV, $\mathrm{HCV}, \mathrm{HBsAg}$, and $\mathrm{TORCH}$ results were negative. Blood subgroups could not be studied.

For the further investigation of causes of hemolytic anemia, I performed hemoglobin electrophoresis and some laboratory analysis of the patient's family members which are presented in Table 1 .

Because, the $\mathrm{Hb}$ was $6.9 \mathrm{~g} / \mathrm{dL}$ and Hct $22.0 \%$ at the moment of hospitalization, I transfused erythrocyte suspension at a dose of $10 \mathrm{ml} / \mathrm{kg}$. The post-transfusion control hemogram revealed $\mathrm{Hb}$ of $9.4 \mathrm{~g} / \mathrm{dL}$ and Hct of $33.2 \%$. After the improvement of the general condition of the patient, he was discharged from the hospital.

Three months later the patient admitted to the hospital with complaints of fatigue, icterus and diarrhea. Follow-up results of the third month were as: Leukocyte count, 6.1 $/ \mathrm{L}$; Hb, $7.5 \mathrm{~g} / \mathrm{dL}$; Hct, 25.2\%;

Table 1. Hemoglobin electrophoresis and certain laboratory values of the patient and family members

\begin{tabular}{|c|c|c|c|c|c|c|c|c|c|c|c|}
\hline & $\begin{array}{l}\mathrm{Hb} \\
\mathrm{g} / \mathrm{dL}\end{array}$ & $\begin{array}{l}\text { Hct } \\
\%\end{array}$ & $\begin{array}{c}\text { Erythrocyte } \\
10^{3} / \mu \mathrm{L}\end{array}$ & $\begin{array}{c}\text { MCV } \\
\mathrm{fL}\end{array}$ & $\begin{array}{l}\text { RDW } \\
\%\end{array}$ & $\begin{array}{l}\text { Ferritin } \\
\mathrm{ng} / \mathrm{mL}\end{array}$ & $\begin{array}{l}\mathrm{SD} \mu \mathrm{g} / \mathrm{dL} \\
(60-180)\end{array}$ & $\begin{array}{l}\mathrm{SIBC} \mu \mathrm{g} / \mathrm{dL} \\
(155-355)\end{array}$ & $\begin{array}{c}\mathrm{HbA}_{2} \% \\
(1.5-3.7)\end{array}$ & $\begin{array}{l}\mathrm{HbA} \% \\
(94-99)\end{array}$ & $\begin{array}{l}\mathrm{HbF} \% \\
(0-2)\end{array}$ \\
\hline Patient & 6,9 & 22.0 & 4.06 & 63.3 & 18.2 & $\begin{array}{l}254.9 \\
(6-24)\end{array}$ & 51 & 205 & 4.20 & 76.10 & 19.7 \\
\hline Sister & 11.7 & 35.5 & 5.11 & 71 & 13.9 & $\begin{array}{c}80.2 \\
(6-24)\end{array}$ & 30 & 294 & 2.65 & 96.91 & 0.44 \\
\hline Father & 12.1 & 36.5 & 7.09 & 56 & 13.1 & $\begin{array}{c}108.5 \\
(23-70)\end{array}$ & 45 & 207 & 5.03 & 94.75 & 0.22 \\
\hline Mother & 10.6 & 31.2 & 4.87 & 68 & 14.6 & $\begin{array}{c}25.2 \\
(23-70)\end{array}$ & 7 & 431 & 2.65 & 96.91 & 0.44 \\
\hline
\end{tabular}

$\mathrm{Hb}$, hemoglobin; Hct, hematocrit; MCV, mean corpuscular volume; RDW, red cell distribution width; SIBC, serum iron-binding capacity. 
platelets, $257.000 \mu / \mathrm{L}$; MCV, $67 \mathrm{fL}$; MCH, $19.8 \mathrm{pg}$; MCHC, 29.8 g/dL; RDW, 17.9\%; T.bil, 5.13mg/ dL; D.bil, 0.69 mg/dL; LDH, 392 U/L; iron, $81 \mu \mathrm{g} /$ dL; serum iron-binding capacity (SIBC), $205 \mu \mathrm{g} / \mathrm{dL}$; CRP, $0.94(0-0.5) \mathrm{mg} / \mathrm{dL}$; and ferritin, $510.1 \mathrm{ng} /$ $\mathrm{mL}$. Haptoglobin was $<5.83 \mathrm{mg} / \mathrm{dL}(36-195)$, while hemoglobin $(+++)$ in the urine and microscopy revealed no erythrocyte. The tests performed to verify intravascular hemolysis due to G6PD deficiency revealed that the reticulocyte count, absolute reticulocyte number and corrected reticulocyte percentage were $4.8 \%, 225.6 \times 10^{3} / \mu \mathrm{L}$ and 2.68 , respectively. Hemoglobinuria disappeared during follow-up. Due to the low $\mathrm{Hb}(7.5 \mathrm{~g} / \mathrm{dL})$ and $\mathrm{Hct}(25.2 \%)$ values, I transfused another erythrocyte suspension at a dose of $15 \mathrm{ml} / \mathrm{kg}$.

In addition to the previous hemoglobin electrophoresis findings of the patient and family, the heterozygous codon 15G/A mutation was found on PCR DNA sequence analysis performed for the beta-globulin (HBB) gene 1,2 and 3 exons. However, alpha thalassemia deletion could not be analyzed. The findings suggested thalassemia trait. The patient was lost to followup after the family moved to another city.

\section{Discussion}

Viral hepatitis is the most common etiological factor of acute hepatitis in childhood in the world and in Turkey. Today the viral hepatitis infection is still important as it was in the past ${ }^{6}$. More than $90 \%$ of children younger than 5 years living in a low socioeconomic community and more than $90 \%$ of young adults of developing countries have a history of acute HAV. However, only $10 \%$ of children under the age of 15 experience the infection in developed countries and there are some countries where young adults have never encountered HAV.

Although Turkey is considered to be a region with a moderate level of endemicity in terms of HAV infection, infection rates can vary according to the geographical region and socio-economic level, particularly in parts where the seroprevalance of HAV infection varies between $85-100 \%$.

Viral hepatitis is a systemic infection that primarily affects the liver, and is characterized by hepatic cell necrosis and inflammation. Acute HAV infection is the primary inflammatory acute infection where the causative agent is the Hepatitis A virus of the Picornaviridae family. The virus can also infect other tissues, however the clinical picture is almost entirely due to inflammation of the liver. The infection can cause various acute clinical scenarios from being asymptomatic to fulminant hepatitis. However, its most important feature differentiating it from other hepatitis types is the lack of chronicity. The complications of acute HAV infection can be observed in two forms as hepatic (recurrent, fulminant cholestatic and autoimmune hepatitis) and extrahepatic (skin, nervous system, urinary system, gastrointestinal tract, and hematological system) involvement ${ }^{8}$.

Hemolytic anemia has been reported as a complication of acute hepatitis in $23 \%$ of the patients. However, the hemolytic anemia incidence can increase up to $70-87 \%$ in patients with G6PD deficien$\mathrm{cy}^{9}$. A study performed by Chau et al. showed that the acute hemolysis incidence was 4\% (17/434) in patients with acute HAV and reported G6PD deficiency in only $53 \%(9 / 17)$ of the patients with acute hemolysis9. Another study found the association of G6PD deficiency and acute HAV infection as $9 \%$ $(18 / 200)$ and reported that hemolysis was observed in $44 \%(8 / 18)$ of these patients ${ }^{10}$.

G6PD is an enzyme with an important role in the redox metabolism of all aerobic cells. G6PD deficiency is estimated to affect around 400 million people worldwide and it is the most common erythrocyte enzyme deficiency. The disorder is most frequently encountered in tropical Africa and Asia, the Middle East, the Mediterranean region and Papua New Guinea $(5-25 \%)^{11}$. The frequency of this enzyme deficiency in Turkey is reported to vary between 0.5 and $20 \%$ depending on the geographical area and/or ethnic group $^{12}$.

Clinical findings in G6PD deficiency are acute hemolytic anemia triggered by exogenous agents, non-spherocytic chronic hemolytic anemia, neonatal jaundice, and favism. Acute hemolysis can develop with oxidative stress in these patients. Multiple drugs, fava and infections have been reported to trigger the acute hemolytic anemia in G6PD deficiency. The acute form of hemolytic anemia seen with fava (Viciafaba) consumption is called favism ${ }^{13}$. Vetch (Vicia sativa) is a feed plant from the favas (Fabaceae) family and has an important place in animal nutrition. Vetch (Vicia sativa) has been reported to trigger hemolysis and cause severe hemolytic anemia in an eight-year-old patient with G6PD deficiency ${ }^{14}$. 
The severity and duration of hemolysis in patients with G6PD deficiency is variable. Signs develop within two-three days after the intake of the oxidative substance. Development of hemoglobinuria, described as dark-colored or cola-like urine, is inevitable after intravascular hemolysis ${ }^{13}$. Although the smear findings primarily indicated thalassemia (target cells) in my patient, there was three-positive hemoglobin in the urine with no erythrocytes on urine microscopy. The G6PD level was checked for intravascular hemolysis and was found to be low. However, haptoglobin was within normal limits as $40 \mathrm{mg} / \mathrm{dL}$ (36-195). Hemoglobin analysis in the urine was repeated during an acute hemolytic attack three months later and was three-positive again. There was no erythrocyte on urine microscopy and the haptoglobin level was low at $<5.83 \mathrm{mg} /$ dL. Normal haptoglobin levels at the beginning may depend (may it began to decrease) on the priorly increased haptoglobulin level. Depending on the haptoglobin consumption, its level decreases with hemolysis, while the level can be normal when the production is also increased in response to infection/inflammation.

Inherited hemoglobin disorders (sickle cell anemia and thalassemia) are among the most common inherited single gene disorders. About $1.5 \%$ of the world's population (80-90 million people) is estimated to carry the beta thalassemia trait. The prevalence of beta thalassemia is high in Mediterranean countries, the Middle East, Asia, Southeast China, and Far East countries as well as the North African coast and South America ${ }^{17,18}$. The frequency of beta thalassemia in Turkey was found $2.1 \%{ }^{16}$.

The mean prevalence of thalassemia trait was $5.2 \%$ and the frequency of G6PD deficiency in males was $1.3 \%$ in a study conducted on the Calabrian community of South Italia. The possibility of inheriting both abnormalities in the heterozygous form was reported $0.13 \%$ in females and $0.07 \%$ in males ${ }^{15}$.

The beta thalassemia trait frequency in Turkey was reported $2.1 \%$ while the G6PD enzyme deficiency rate varied between 0.5 and $20 \%{ }^{12,16}$. However, I could not find any information on the possibility of co-inheritance of both abnormalities together in a heterozygous form. I assume that the possibility of co-inheritance should be considered when evaluating patients in communities where both diseases are commonly seen.

Patients with a clinical and hematological picture not severe as thalassemia major, but experiencing a more severe course than thalassemia minor are considered to have thalassemia intermedia. Thalassemia intermedia's clinic is also very heterogenous. It may be completely asymptomatic until adulthood and is usually characterized only by a mild anemia that does not require transfusion in the majority of patients. Patients with thalassemia intermedia with a more severe clinical picture are usually diagnosed between the ages of 2-6 years and continue their life without requiring transfusions or transfusions are rarely required. However, growth and developmental delay can be present ${ }^{17,18}$. In my case, thalassemia intermedia was considered, because patient was 3 years old, suffered from developmental delay, and required transfusion. In addition, the growth and development delay would have been associated with the chronic anemia and low socioeconomic status (malnutrition). However, the patient's mother was not a carrier of thalasemia and PCRDNA sequence analysis revealed a heterozygous codon $15 \mathrm{G} / \mathrm{A}$ mutation, pointing more towards thalassemia trait than thalassemia intermedia.

Beta thalassemia trait can appear in three different ways:

The first is the $\beta$-thalassemia trait with high $A 2$ which is the most common $\beta$-thalassemia trait type with $\mathrm{HbA} 2$ values of $3.5-8 \%$ and $\mathrm{HbF}$ values of $1-5 \%$. Most of the single base mutations that result in $\beta$-thalassemia typically cause elevated $\mathrm{HbA} 2$ in the carriers. $\beta+$ and $\beta 0$ mutations result in different clinical appearances in the heterozygote patients. Transfusion-dependent anemia is seen in homozygous children together with the thalassemia intermedia phenotype at times. My patient was heterozygous but the $\mathrm{HbF}$ value was higher than the carriers (19.7\%).

The second is the $\beta$-thalassemia trait with normal A2. The HbA2 level is low or normal. This type of $\beta$-thalassemia trait should be differentiated from silent carriers with hypochromous hypocytic anemia. Both the $\beta$ and $\delta$ gene are damaged in the same chromosome or separate chromosomes. The homozygous child is severely affected when one of the parents has the same type and the other is a classical carrier. I did not consider this kind of $\beta$-thalassemia trait in my patient, as the $\mathrm{HbA} 2$ level was high.

The third $\beta$-thalassemia trait is with high A2 and high $\mathrm{F}$. This is a different variant. Both $\mathrm{HbA} 2$ and $\mathrm{HbF}$ (5$20 \%)$ levels are high. $\beta$ gene deletion is present, but the $\delta$ and $\gamma$ genes are intact ${ }^{19}$. The high levels of both $\mathrm{HbA} 2$ (4.20\%) and $\mathrm{HbF}(19.7 \%)$ in my patient indicated the presence of this type of $\beta$-thalassemia. 
I was unfortunately unable to investigate the patient further (for alpha thalassemia deletion, etc.) as he was lost during the follow-up. However, I believe that it would be informative to share the concurrence of these three disorders as I have not come across any similar reports in the literature.

In conclusion, the hemoglobinopathies, thalassemias and G6PD deficiency are inherited erythrocyte disorders that are commonly seen in various regions of the world including Africa, the Mediterranean region and Asia. Acute hepatitis $\mathrm{A}$ infection is an infectious disease that is also common in the same regions. Intravascular hemolysis and coinheritance of different disorders must be considered and peripheral smear (erythrocyte morphology) and urine microscopy should not be neglected if anemia and significant hyperbilirubinemia are present in patients with hepatitis A infection. Patients deficient with the G6PD enzyme activity, and particularly the health care employees should be vaccinated against the hepatitis $A$ and hepatitis B viruses, particularly in areas where these viruses are endemic.

\section{Conflict of Interest Statement}

The author of this paper has no conflicts of interest, including specific financial interests, relationships, and/ or affiliations relevant to the subject matter or materials included.

\section{References}

1. Pornprasert $S$, Phanthong S. Anemia in patients with coinherited thalassemia and glucose-6-phosphate dehydrogenase deficiency. Hemoglobin 2013;37:536-43.

2. Mert A, Tabak F, Ozturk R, et al. Acute viral hepatitis with severe hyperbilirubinemia and massive hemolysis in glucose6-phosphate dehydrogenase deficiency. J Clin Gastroenterol 2001;32:461-2.

3. OzbayHosnut F, Ozcay F, Selda Bayrakci U, et al. Etiology of hemolysis in two patients with hepatitis A infection: glucose-6phosphate dehydrogenase deficiency or autoimmune hemolytic anemia. Eur J Pediatr 2008;167:1435-9.
4. Charan VD, Desai N, Choudhury VP. Hyperbilirubinemia following hepatitis A in a patient with G6PD deficiency. Indian J Gastroenterol 1993;12:99.

5. Stein M, Tomer Y, Shoenfeld Y. Extreme bilirubinemia in hepatitis A associated with G6PD-deficiency. Harefuah 1990;119:126-8.

6. Mıstık R. Türkiye'de viral hepatit epidemiyolojisi-yayınların irdelenmesi. In: Tabak F, Balık İ, Tekeli E, editors. İstanbul: Viral Hepatitle Savaşım Derneği; 2007. p.9-51.

7. Dökmetaş İ. HAV enfeksiyonunun epidemiyolojisi ve patogenezi. In: Tabak F, Balık İ, Tekeli E, editors. İstanbul: Viral Hepatitle Savaşım Derneği; 2007:52-60.

8. Bell BP, Shapiro CN, Margolis HS. Hepatitis A virus. In: Feigin RD, Cherry JD, Demmler GJ, et al editors. Textbook of pediatric infectious diseases. Philadelphia, Pennsylvania: Saunders Elsevier; 2004:2069-86.

9. Chau TN, Lai ST, Lai JY, et al. Haemolysis complicating acute viral hepatitis in patients with normal or deficient glucose6-phosphate dehydrogenase activity. Scand J Infect Dis 1997;29:551-3.

10. Gotsman I, Muszkat M. Glucose-6-phosphate dehydrogenase deficiency is associated with increased initial clinical severity of acute viral hepatitis A. J GastroenterolHepatol 2001;16:1239-43.

11. Drousiotou A, Touma EH, Andreou N, et al. Molecular characterization of G6PD deficiency in Cyprus. Blood Cells Mol Dis 2004;33:25-30.

12. Altay C, Gümrük F. Red cell glucose-6-phosphate dehydrogenase deficiency in Turkey. Turk J Hematol 2008;25:1-7.

13. Luzatto L, Poggi V. Glucose-6-phosphate dehyrdogenase deficiency. In: Orkin SH, Nathan DG, Ginsburg D, et al editors. Nathan and oski's hematology of infant and childhood. Philadelphia: Saunders Elsevier; 2009:883-907.

14. Bicakci Z. A hemolysis trigger in glucose-6-phosphate dehydrogenase enzyme deficiency. Vicia sativa (Vetch). Saudi Med J 2009;30:292-4.

15. Tagarelli A, Piro A, Bastone L, et al. Identification of glucose 6-phosphate dehydrogenase deficiency in a population with a high frequency of thalassemia. FEBS Lett 2000;466:139-42.

16. Cavdar AO, Arcasoy A. The incidence of thalassemia and abnormal hemoglobins in Turkey. Acta Haematol 1971;45:312-8.

17. Galanello R, Origa R. Beta-thalassemia. Orphanet J Rare Dis 2010;5:11.

18. Haddad A, Tyan P, Radwan A, et al. $\beta$-Thalassemia intermedia: a bird's-eye view. Turk J Haematol 2014;31:5-16.

19. Cunningham MJ, SankaranVG, Nathan DG, et al. The Thalassemias. In: Orkin SH, Nathan DG, Ginsburg D, et al editors. Nathan and oski's hematology of infant and childhood. Philadelphia: Saunders Elsevier; 2009:1015-106. 